() О. І. Хмілярчук, канд. техн. наук, доцент, М. О. Клішина, студентка, КПІ ім. Ігоря Сікорського, Київ, Україна

\title{
ТЕХНОЛОГІЧНІ ОСОБЛИВОСТІ ВИГОТОВЛЕННЯ ВИДАНЬ ЗІ ЗМІННИМИ ЕЛЕМЕНТАМИ БЛОКУ
}

У статті представлено результати аналізу переваг та недоліків видань, що мають у своїй структурі змінні елементи. Проаналізовано брошурувально-палітурні операції для випуску представленого виду видань, розроблено їх блок-схеми виготовлення; порівняно кількість ручних операцій, витрати часу на виконання ручних операцій та виготовлення видання в цілому.

\section{Ключові слова: конструкція видання; змінні елементи видань; вид скріплення зошитів; ручні операції; післядрукарські операції; технологічні особливості виготовлення.}

\section{Постановка проблеми}

Завдяки виникненню нових матеріалів та технологій з'являється можливість створення сучасних типів конструкцій книг, які неможливо було уявити раніше. Це все відбувається частково від того, що людині з кожним роком стає менш цікаво спостерігати щось одноманітне, та щоб здивувати, зацікавити користувачів, бути конкурентоспроможними на ринку майбутнього, книга має подолати не одну межу перешкод та перетворень.

Проведені раніше дослідження [1] показали, що конструкції зі змінними зошитами, поступово набувають поширення у різних сферах життя людей. Особливо це спостерігається в економічній та творчій діяльності. Але впровадження цих видань в активне виробництво сповільнене низкою чинників, зокрема й неможливістю уникнення ручних операцій.
Аналіз попередніх досліджень

У видавничій справі за останній час сталася цифрова революція, все більш зростає популярність електронної книги, тож, щоб діяти, розвиватися згідно вимог часу, вигідно вирізнятися серед іншої продукції, необхідно знаходити нові рішення для більш зручного використання видань.

Зовнішній вигляд книги, її формат, з'єднання блоку з палітуркою, колірність видання, верстка впливають на тактильне, зорове та естетичне сприйняття читача, а отже і на розповсюдженість видань. Поширення таких ексклюзивних видань у світі наразі стає все більш актуальним. Географія досліджених конструкцій видань [2-10] розповсюджується на численну кількість країн. Серед них $€$ також країни-розробники видань, що запатентовані в останні роки, 
a саме: США, Великобританія, Іспанія, Італія, Німеччина.

В Україні також спостерігається схильність покупців до цікавих конструкцій видань, а саме продукцією сувенірного, подарункового, рекламного, колекційного типів.

В результаті огляду та аналізу розглянутої літератури, інтернет-ресурсів та запатентованих проектів розроблено загальну класифікацію видань зі змінними елементами [1] за такими ознаками: обсяг змінних елементів, вид скріплення, палітурні матеріали та призначення.

\section{Мета роботи}

Розроблення оптимальних технологічних процесів виготовлення видань зі змінними зошитами та рекомендацій щодо їх застосування.

\section{Результати проведених досліджень}

За результатами попередніх досліджень було виділено найпопулярніші конструкції видань зі змінними елементами, а саме: видання зі скріпленням на кільця, на металеві тримачі, на резинки, пластиковим диском, видання 3 магнітним корінцем, видання зі стрижнем, зі скріпкошиною, з системою застібок оригамі. Аналіз переваг та недоліків даних конструкцій зазначено у таблиці.

Зміни у традиційній конструкції видань перш за все впливають на післядрукарські процеси (брошурувально-палітурні операції). За результатами аналізу брошурувально-палітурних технологічних процесів видань зі змінними елементами, було розроблено схеми до кожної конструкції та визначено кількість ручних операцій.

Видання, що скріплюється на кільця.

Загальна схема виготовлення: Т1У1 $\rightarrow$ T2У2 $\rightarrow$ Т3У3 $\rightarrow$ T4Y4 $\rightarrow$ T5Y5 $\rightarrow$ T6Y2 $\rightarrow$ T7Y6 $\rightarrow$ T8Y2 $\rightarrow$ T9y2 $\rightarrow$ T10Y7 $\rightarrow$ T11Y8 $\rightarrow$ T12У9 $\rightarrow$ Т13У10.

Пояснення до схеми: Т технологічні операції: Т1 - друк накладу та покривного матеріалу для палітурки; Т2 - розрізка віддрукованих аркушів; Т3 фальцювання зошитів блоку; Т4 пресування зошитів; Т5 - комплектування блоку (підбирання зошитів); Т6 - обрізка блоку з 3-х сторін; Т7 - перфорація; Т8 розрізка покривного матеріалу; Т9 - розкрій картону на боковини й відстав; Т10 - виготовлення палітурки; Т11 - встановлення системи кілець у палітурку; Т12 - вставка блоку в палітурку; Т13 - пакування. У - устаткування: У1 - офсетна друкарська машина; У2 - одноножова різальна машина; УЗ - фальцювальна машина; У4 - прес; У5 аркуше- та зошитопідбірна машина; У6 - машина для перфорації; У7 - машина для виготовлення палітурок; У8 - ручне встановлення системи кілець; у9 - півавтоматична блоковставна машина; У10 - пакувальна машина.

Видання зі скріпленням на диск.

Загальна схема виготовлення: Т1У1 $\rightarrow$ Т2У2 $\rightarrow$ Т3У3 $\rightarrow$ T4У4 $\rightarrow$ T5Y5 $\rightarrow$ T6У2 $\rightarrow$ T7Y6 $\rightarrow$ T8Y7 $\rightarrow$ T9y8.

Пояснення до схеми: Т технологічні операції: Т1 - друк накладу; Т2 - розрізка паперу 
для блоку та обкладинок; Т3 фальцювання зошитів блоку; Т4 пресування зошитів; Т5 - комплектування блоку (підбирання зошитів); Т6 - обрізка блоку та обкладинки з 4-х сторін; Т7 перфорація; Т8 - встановлення дисків у обкладинку та блок; Т9 пакування. У - устаткування: У1 офсетна друкарська машина; У2 одноножова різальна машина; У3 - фальцювальна машина; У4 прес; У5 - аркуше- та зошитопідбірна машина; У6 - машина

Переваги та недоліки видів скріплення видань зі змінними елементами порівняно з традиційним шиттям нитками

\begin{tabular}{|c|c|c|}
\hline Вид скріплення & Переваги & Недоліки \\
\hline З’єднання на кільця & $\begin{array}{l}\text { можливість заміни окремих } \\
\text { сторінок }\end{array}$ & $\begin{array}{l}\text { недостатньо міцне } \\
\text { скріплення; } \\
\text { можливість розривання } \\
\text { сторінок у місці } \\
\text { приєднання }\end{array}$ \\
\hline Скріплення на диск & $\begin{array}{l}\text { легкість прикріплення чи } \\
\text { розділення сторінок }\end{array}$ & $\begin{array}{l}\text { повільна заміна елементів; } \\
\text { використання лише } \\
\text { окремих аркушів; } \\
\text { неможливість зміни великої } \\
\text { кількості змінних елементів } \\
\text { одночасно }\end{array}$ \\
\hline $\begin{array}{l}\text { Скріплення на металеві } \\
\text { тримачі (гачки) }\end{array}$ & \begin{tabular}{|l|} 
багатофункціональна зміна \\
порядку зошитів; \\
можливість \\
перезаряджування блоку
\end{tabular} & $\begin{array}{l}\text { трудомісткість витягування } \\
\text { окремих зошитів з блоку; } \\
\text { можливість заміни тільки } \\
\text { зошитів }\end{array}$ \\
\hline Скріплення на резинки & інтерактивне використання & $\begin{array}{l}\text { більша трудомісткість при } \\
\text { заміні зошитів }\end{array}$ \\
\hline Скріпкошина & $\begin{array}{l}\text { міцне скріплення; } \\
\text { швидке, зручне роз'єднан- } \\
\text { ня; } \\
\text { можливість використання } \\
\text { в якості змінних елементів } \\
\text { як сторінок, так і зошитів }\end{array}$ & $\begin{array}{l}\text { обмежений об'єм змінних } \\
\text { елементів }\end{array}$ \\
\hline З магнітним корінцем & $\begin{array}{l}\text { можливість зручного } \\
\text { роз'єднання елементів; } \\
\text { швидке } \\
\text { приєднання/роз'єднання }\end{array}$ & $\begin{array}{l}\text { приєднання зайвих мета- } \\
\text { левих предметів, що зна- } \\
\text { ходяться у межах магніт- } \\
\text { ного впливу; } \\
\text { недостатньо міцне скріп- } \\
\text { лення елементів }\end{array}$ \\
\hline З дерев'яним стрижнем & $\begin{array}{l}\text { простота у виготовленні } \\
\text { видання }\end{array}$ & $\begin{array}{l}\text { втрата головного елементу } \\
\text { (стрижню) призводить до } \\
\text { руйнування усієї конст- } \\
\text { рукції; } \\
\text { складність заміни елемен- } \\
\text { тів }\end{array}$ \\
\hline $\begin{array}{l}\text { З системою застібок } \\
\text { оригамі }\end{array}$ & $\begin{array}{l}\text { легке витягування } \\
\text { елементів; }\end{array}$ & $\begin{array}{l}\text { можливість використання в } \\
\text { якості змінних елементів як } \\
\text { сторінок, так і зошитів } \\
\text { швидке зношення застібок; } \\
\text { ненадійність конструкції }\end{array}$ \\
\hline
\end{tabular}


для перфорації; У7 - ручне встановлення дисків; У8 - пакувальна машина.

Видання зі скріпленням на металеві тримачі.

Загальна схема виготовлення: Т1У1 $\rightarrow$ Т2У2 $\rightarrow$ Т3У3 $\rightarrow$ T4У4 $\rightarrow$ T5Y5 $\rightarrow$ T6Y7 $\rightarrow$ T7Y2 $\rightarrow$ T8Y2 $\rightarrow$ T9Y2 $\rightarrow$ T10Y8 $\rightarrow$ T11y9 $\rightarrow$ $\mathrm{T} 12 \mathrm{Y} 10 \rightarrow \mathrm{T} 13 \mathrm{Y} 11$.

Пояснення до схеми: Т технологічні операції: Т1 - друк накладу та покривного матеріалу для палітурки; Т2 - розрізування паперу для блоку та палітурки; ТЗ - фальцювання зошитів блоку; Т4 - пресування зошитів; Т5 - комплектування блоку (підбирання зошитів); Т6 шиття дротом; Т7 - обрізка блоку з 3-х сторін; Т8 - розрізка покривного матеріалу; Т9 - розкрій картону на боковини і відстав; Т10 - виготовлення палітурки типу 7; Т11 - встановлення системи металевих тримачів (гачків); Т12 - вставка блоку в палітурку; Т13 - пакування. У устаткування: У1 - офсетна друкарська машина; У2 - одноножова різальна машина; УЗ фальцювальна машина; У4 прес; У5 - аркуше- та зошитопідбірна машина;У7 - ВШРА; У8 - машина для виготовлення палітурок; у9 - ручне встановлення системи металевих тримачів (гачків); У10 - ручне встановлення блоку у палітурку; У11 пакувальна машина.

Видання зі скріпленням на резинки.

Загальна схема виготовлення: Т1У1 $\rightarrow$ T2У2 $\rightarrow$ Т3У3 $\rightarrow$ T4Y4 $\rightarrow$ T5Y5 $\rightarrow$ T6У7 $\rightarrow$ T7Y2 $\rightarrow$ T8Y2 $\rightarrow$ T9Y2 $\rightarrow$ T10Y8 $\rightarrow$ T11Y9 $\rightarrow$ $\mathrm{T} 12 \mathrm{Y} 10 \rightarrow \mathrm{T} 13 \mathrm{Y} 11$.
Пояснення до схеми: Т технологічні операції: Т1 - друк накладу та покривного матеріалу для палітурки; Т2 - розрізування паперу для блоку та палітурки; Т3 - фальцювання зошитів блоку; Т4 - пресування зошитів; Т5 - комплектування блоку (підбирання зошитів); Т6 шиття дротом; Т7 - обрізка блоку з 3-х сторін; Т8 - розрізка покривного матеріалу; Т9 - розкрій картону на боковини і відстав; Т10 - виготовлення палітурки типу 7; Т11 - встановлення системи резинок; Т12 вставка блоку в палітурку; Т13 пакування. У - устаткування: У1 офсетна друкарська машина; У2 - одноножова різальна машина; УЗ - фальцювальна машина; У4 - прес; У5 - аркушета зошитопідбірна машина; У7 ВШРА; У8 - машина для виготовлення палітурок; У9 - ручне встановлення системи резинок; У11 - пакувальна машина.

Видання зі скріпкошиною.

Загальна схема виготовлення: Т1У1 $\rightarrow$ T2У2 $\rightarrow$ Т3У3 $\rightarrow$ T4Y4 $\rightarrow$ T5Y5 $\rightarrow$ T6Y2 $\rightarrow$ T7Y2 $\rightarrow$ T8Y2 $\rightarrow$ T9y6 $\rightarrow$ T10y7 $\rightarrow$ T11Y8 $\rightarrow$ T12y9.

Пояснення до схеми: Т технологічні операції: Т1 - друк накладу та покривного матеріалу для палітурки; Т2 - розрізування паперу для блоку та палітурки; Т3 - фальцювання зошитів блоку; Т4 - пресування зошитів; Т5 - комплектування блоку (підбирання зошитів); Т6 - обрізка блоку з 3-х сторін; Т7 розрізка покривного матеріалу; Т8 - розкрій картону на боковини і відстав; Т9 - виготовлення палітурки типу 7; Т10 - встановлення скріпкошини; Т11 - 
вставка зошитів у скріпкошину; Т12 - пакування. У - устаткування: У1 - офсетна друкарська машина; У2 - одноножева різальна машина; УЗ - фальцювальна машина; У4 - прес; У5 аркуше- та зошитопідбірна машина; У6 - машина для виготовлення палітурок; У7 - ручне встановлення скріпкошини; У8 ручна вставка зошитів у скріпкошину; У9 - пакувальна машина.

Видання з магнітним корінцем.

Загальна схема виготовлення: Т1У1 $\rightarrow$ T2У2 $\rightarrow$ Т3У3 $\rightarrow$ T4У4 $\rightarrow$ T5Y5 $\rightarrow$ T6Y6 $\rightarrow$ T7Y2 $\rightarrow$ T8Y2 $\rightarrow$ T9Y2 $\rightarrow$ T10Y7 $\rightarrow$ T11Y8 $\rightarrow$ T12У9 $\rightarrow$ T13У10.

Пояснення до схеми: Т технологічні операції: Т1 - друк накладу та покривного матеріалу для палітурки; Т2 - розрізування паперу для блоку та палітурки; ТЗ - фальцювання зошитів блоку; Т4 - обробка корінця сторінок магнітним вінілом; Т5 пресування зошитів; Т6 - комплектування блоку (підбирання зошитів); Т7 - обрізка блоку з 3-х сторін; Т8 - розрізка покривного матеріалу; Т9 - розкрій картону на боковини і відстав; Т10 - виготовлення палітурки типу 7; Т11 - виготовлення та встановлення металевого стрижню (з діаметральними магнітами всередині); Т12 - вставка блоку в палітурку; Т13 - пакування. У - устаткування: У1 офсетна друкарська машина; У2 - одноножова різальна машина; УЗ - фальцювальна машина; У4 - ручне оброблення сторінок магнітним вінілом;У5 прес; У6 - аркуше- та зошитопідбірна машина;У7 - машина для виготовлення палітурок; У8 ручне виготовлення та встанов- лення металевого стрижню; У9 ручне встановлення блоку в палітурку; У10 - пакувальна машина.

Видання здерев'яним стрижнем.

Загальна схема виготовлення: T1Y1 $\rightarrow$ T2У2 $\rightarrow$ Т3У3 $\rightarrow$ T4Y4 $\rightarrow$ T5Y5 $\rightarrow$ T6У2 $\rightarrow$ T7Y6 $\rightarrow$ T8Y7 $\rightarrow$ T9У 10 .

Пояснення до схеми: Т технологічні операції: Т1 - друк накладу та матеріалу для обкладинки; Т2 - розрізка віддрукованих аркушів; Т3 - фальцювання зошитів блоку; Т4 - пресування зошитів; Т5 - комплектування блоку (підбирання зошитів); Т6 обрізка блоку з 3-х сторін; Т7 перфорація зошитів та обкладинки; Т8 - вставка дерев'яного стрижню у блок; Т9 - пакування. У - устаткування: У1 - офсетна друкарська машина; У2 одноножова різальна машина; У3 - фальцювальна машина; У4 - прес; У5 - аркуше- та зошитопідбірна машина; У6 - машина для перфорації; У7 - ручне встановлення дерев'яного стрижню; У10 - пакувальна машина.

Видання з системою застібок оригамі.

Загальна схема виготовлення: Т1У1 $\rightarrow$ T2У2 $\rightarrow$ Т3У3 $\rightarrow$ T4У4 $\rightarrow$ T5Y5 $\rightarrow$ T6Y7 $\rightarrow$ T7Y2 $\rightarrow$ T8Y2 $\rightarrow$ T9Y2 $\rightarrow$ T10Y8 $\rightarrow$ T11Y9 $\rightarrow$ $\mathrm{T} 12 \mathrm{Y} 10 \rightarrow \mathrm{T} 13 \mathrm{Y} 11$.

Пояснення до схеми: Т технологічні операції: Т1 - друк накладу та покривного матеріалу для палітурки; Т2 - розрізування паперу для блоку та палітурки; Т3 - фальцювання зошитів блоку; Т4 - пресування зошитів; Т5 - комплектування блоку (підбирання зошитів); Т6 - шиття дротом; 77 - обрізка блоку з 3-х сторін; Т8 - розрізка покривного 
матеріалу; Т9 - розкрій картону на боковини і відстав; Т10 - виготовлення палітурки типу 7; Т11 - виготовлення та встановлення застібок оригамі; Т12 вставка зошитів у застібки оригамі; Т13 - пакування. У - устаткування: У1 - офсетна друкарська машина; у2 - одноножова різальна машина; У3 фальцювальна машина; У4 прес; У5 - аркуше- та зошитопідбірна машина; У7 - ВШРА; У8 - машина для виготовлення палітурок; у9 - ручне виготовлення та встановлення застібок оригамі; У10 - ручна вставка зошитів у застібки оригамі; У11 — пакувальна машина.

Згідно розроблених схем брошурувально-палітурних технологічних процесів видань зі змінними елементами, проаналізовано кількість ручних операцій на післядрукарській стадії та побудовано порівняльну діаграму кількості ручних операцій, що зображено на рис. 1. Оскільки кількість операцій не завжди корелюється з часом на їх виконання, проведено розрахунки тривалості виконання ручних операцій на післядрукарській стадії, сумарний час яких зображено на рис. 2.

Але одним з головних показників технологічності системи $€$ саме загальний час виробництва видання $[11,12]$. Через це доцільним $€$ проведення аналізу загального часу виготовлення видання та більш детальне вивчення загального часу ручних операцій на післядрукарській стадії.

За результатами досліджень визначено загальний час на виконання друкарських та післядрукарських процесів для кожного виду конструкції. При порівнянні різних видів конструкцій за еталон часу було обрано час виготовлення видання зі скріпленням шиття нитками та палітуркою типу 7. Діаграма проведеного дослідження загального часу на виготовлення видань зі змінними зошитами у відсотках, наведена на рис. 3.

\section{Висновки}

За результатами порівняльного аналізу видань зі змінними елементами, визначено їх пере-

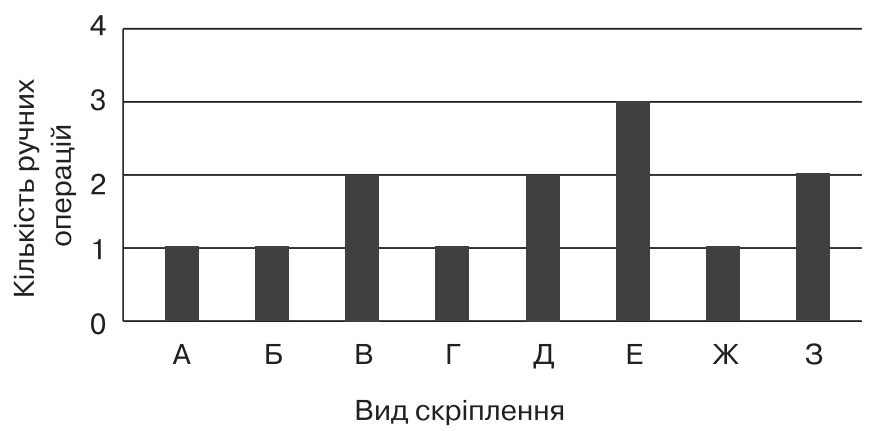

Рис. 1. Порівняльна діаграма кількості ручних операцій на післядрукарській стадії: А - скріплення на кільця; Б - скріплення на диск;

В - скріплення на металеві тримачі; Г - скріплення на резинки; Д - скріплення скріпкошиною; E - скріплення з магнітним корінцем; Ж - скріплення дерев'яним стрижнем; 3 - система застібок оригамі 
Скріплення в палітурку типу 7

3) система застібок оригамі Ж)скріплення дерев'яним стрижнем

Е) скріплення з магнітним корінцем

Д) скріплення скріпкошиною

Г) скріплення на резинки

В) скріплення на металеві тримачі

Б) скріплення на диск

А) скріплення на кільця

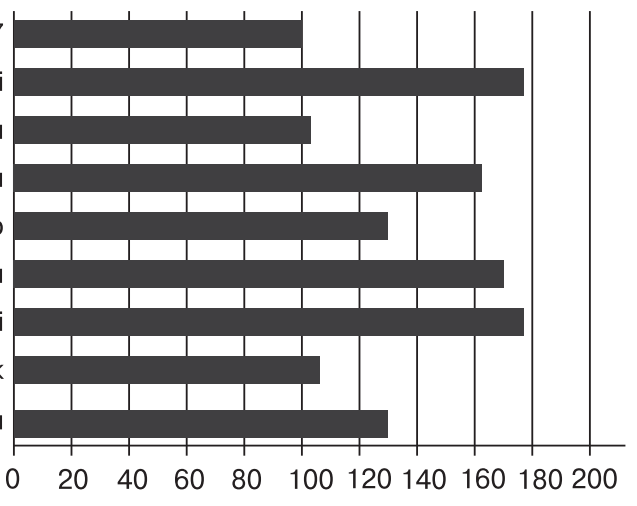

Загальний час на виготовлення видання, \%

Рис. 2. Порівняльна діаграма загального часу виконання ручних операцій на післядрукарській стадії

ваги та недоліки, що дало змогу встановити доцільність використання представлених конструкцій у певних ситуаціях та необхідність аналізу брошурувальнопалітурних операцій виготовлення таких видань.

За результатами аналізу друкарських та післядрукарських процесів розроблено узагальнені схеми виготовлення кожної конструкції, що дало змогу визначити кількість ручних опера- цій та витрати часу на їх виконання. Дослідження показало, що кількість операцій не завжди корелюється з часом на їх виконання. За результатами досліджень визначено загальний час на виконання друкарських та післядрукарських процесів для кожного виду конструкції та встановлено на скільки виготовлення даних конструкцій $€$ тривалішим за виготовлення видання у палітурці типу 7.

3) система застібок оригамі Ж) скріплення дерев'яним стрижнем Е) скріплення з магнітним корінцем

Д) скріплення скріпкошиною

Г) скріплення на резинки

В)скріплення на металеві тримачі

Б) скріплення на диск

А) скріплення на кільця

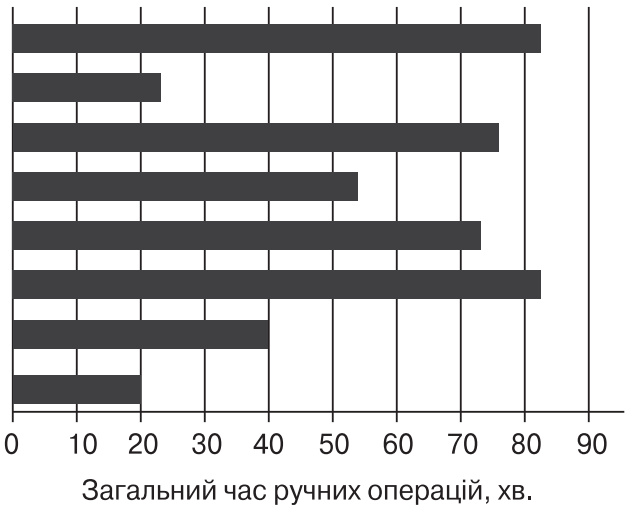

Рис. 3. Діаграма загального часу на виготовлення видань зі змінними зошитами 


\section{Список використаної літератури}

1. О. І. Хмілярчук. Аналіз конструкцій видань зі змінними елементами блоку та сфери їх використання / О. І. Хмілярчук, М. О. Клішина // Технологія і техніка друкарства. 2018. № 3(61). С. 14-20. [Електронний ресурс]. Спосіб доступу: http://ttdruk.vpi.kpi.ua/article/view/155197.

2. Refillable notebook with release mechanism. US $8,876,423 \mathrm{B2}$. Int. $\mathrm{Cl}$. B42F 13/06, B42F 13/02, B42F 13/165 Filed: Oct. 18, 2011. Pub. Date: Nov. 4, 2014.

3. Mobile binding. US 4589682. Int. Cl. B42D 17/00. Filed: Jul. 16, 1985. Pub. Date: May 20, 1986.

4. Magnetically bound medium with reattachable pages. US $2015 / 0224806$ A1. Int. Cl: B42D 13/00; D21H 17/25; D21H 17/67; D21H 17/68; B42D 1/00; D21H 17/00/. Filed: Feb. 12, 2014. Pub. Date: Aug. 13, 2015.

5. Apparatus for holding greeting cards. US 006108952A. Int. Cl: G09F 1/10. Filed: Mar. 26, 1997. Pub. Date: Aug. 29, 2000.

6. Securing tool with swing clip and indicia area. US 2007/0086839 A1. Int. Cl: B42F 3/2. Filed: Sep. 26, 2006. Pub. Date: Apr. 19, 2007.

7. Consecotaleophobia - Editorial Design. [Електронний ресурс]. Спосіб доступу: https://clc.am/ay0n7Q.

8. Encuadernación. Colección de libretas con hojasextraibles. [Електронний ресурc]. Спосіб доступу: http://tinyurl.com/yb8d5pwt.

9. Spiral bound notebook with removable sheets. US 2011/0233913 A1 Int. Cl. B42D 1/0/ Filed: Mar. Mar. 23, 2010. Pub. Date: Sep. 29, 2011.

10. One-piece rigid covers for disc-bound fold-over binding system and use of composite material for making the same. EP 3222437 A1 Int. Cl. B42F 3/00, B42F 13/00 Filed: 23.03.2017. Pub. Date: 27.09.2017. Bulletin 2017/39.

11. Гавенко С. Ф. Оцінка якості поліграфічної продукції / С. Ф. Гавенко, О. В. Мельников. За ред. д-ра техн. наук проф. Е. Т. Лазаренка. Львів: Афіша, 2000. 120 c.

12. С. Ф. Гавенко. Інтегральний прогноз якості книжкових видань / С. Ф. Гавенко, В. М. Сеньківський, Н. Є. Сеньківська // Інформаційні технології і автоматизація поліграфічного виробництва. 2011. № 2. С. 144-148.

\section{References}

1. Khmiliarchuk, O. I. \& Klishyna, M. O. (2018). Analiz konstruktsii vydan zi zminnymy elementamy bloku ta sfery yikh vykorystannia. Journal of Tekhnolohiia $i$ tekhnika drukarstva, 3(61), 14-20. Retrieved from http://ttdruk.vpi.kpi.ua/article/view/155197 [in Ukrainian].

2. Refillable notebook with release mechanism // Patent US 8,876,423 B2. Int. Cl. B42F 13/06, B42F 13/02, B42F 13/165 Filed: Oct. 18, 2011. Pub. Date: Nov. 4, 2014 [in English].

3. Mobile binding // Patent US 4589682. Int. Cl. B42D 17/00. Filed: Jul. 16, 1985. Pub. Date: May 20, 1986 [in English].

4. Magnetically bound medium with reattachable pages // Patent US 2015/0224806 A1. Int. Cl: B42D 13/00; D21H 17/25; D21H 17/67; D21H 17/68; B42D 1/00; D21H 17/00/. Filed: Feb. 12, 2014. Pub. Date: Aug. 13, 2015 [in English].

5. Apparatus for holding greeting cards // Patent US 006108952A. Int. Cl: G09F 1/10. Filed: Mar. 26, 1997. Pub. Date: Aug. 29, 2000 [in English]. 
6. Securing tool with swing clip and indicia area // Patent US 2007/0086839 A1. Int. Cl: B42F 3/2. Filed: Sep. 26, 2006. Pub. Date: Apr. 19, 2007 [in English].

7. Consecotaleophobia - Editorial Design. Retrieved from https://clc.am/ay0n7Q [in English].

8. Encuadernación. Colección de libretas con hojasextraibles. Retrieved from http://tinyurl.com/yb8d5pwt [in English].

9. Spiral bound notebook with removable sheets // Patent US 2011/0233913 A1 Int. Cl. B42D 1/0/ Filed: Mar. Mar. 23, 2010. Pub. Date: Sep. 29, 2011 [in English].

10. One-piece rigid covers for disc-bound fold-over binding system and use of composite material for making the same // Patent EP 3222437 A1 Int. Cl. B42F 3/00, B42F 13/00 Filed: 23.03.2017. Pub. Date: 27.09.2017. Bulletin 2017/39 [in English].

11. Havenko, S. F. \& Melnykov, O. V. (2000). Otsinka yakosti polihrafichnoi produktsii. Lviv: Afisha, 120 p. [in Ukrainian].

12. Havenko, S. F. \& Senkivskyi, V. M. \& Senkivska, N. Ye. (2011). Intehralnyi prohnoz yakosti knyzhkovykh vydan. Journal of Informatsiini tekhnolohii $i$ avtomatyzatsiia polihrafichnoho vyrobnytstva, 2, 144-148 [in Ukrainian].

В статье представлены результаты анализа преимуществ и недостатков изданий, имеющих в своей структуре сменные элементы. Проанализированы брошюровочно-переплетные процессы для выпуска данного вида изданий, разработаны их блок-схемы изготовления; проведено сравнение количества ручных операций, затраты времени на выполнение ручных операций и изготовления издания в целом.

Ключевые слова: конструкция издания; сменные элементы изданий; тип скрепления тетрадей; ручные операции; послепечатные операции; технологические особенности изготовления изданий.

The article presents the results of analysis advantages and disadvantages of editions with variable elements in their structure. Binding operations for productions of this type of editions were analyzed, their block diagrams of production were developed; comparatively the number of manual operations, the time spent on manual operations and the production of the editions as a whole.

Keywords: constructions of editions; variable elements of editions; kind of fastening notebooks; manual operations; postprinting operations; technological features of the production of publications. 